\title{
Anaesthetic management with morphine in phaeochromocytoma
} Chikara Tashiro MD, Tokuichiro Seki PHD, Masahiko Miyata MD, Yasunaru Kawashima MD

Morphine was used as the principal anaesthetic agent for five patients undergoing resection of phaeachromocytoma, and changes in plasma catecholamines were monitored. Phenoxygenzamine $\left(0.5 \mathrm{mg} \cdot \mathrm{kg}^{-1} \cdot \mathrm{day}^{-1}\right)$ was orally given one week before operation. After premedication with hyoscine $(0.4 \mathrm{mg})$ and diazepam $(20 \mathrm{mg})$ of meperidine $(50 \mathrm{mg})$, anaesthesia was induced with an infusion of morphine ( $\left.1 \mathrm{mg} \cdot \mathrm{kg}^{-1}\right)$ over 30 min and maintained with diazepam, nitrous oxide and oxygen. Pancuronium was used as the muscle relaxant. In three of the five patients, blood pressure transiently rose (ranging from 15 to $60 \mathrm{mg}$ ) following orotracheal inubation, but vasodilators were not required. In two of the three, plasma norepinephrine increases were 1.1 and 1.3 $n g \cdot \mathrm{ml}^{-1}$. In the other two patients, whose blood pressure was stable, the change in plasma norepinephrine was 0.1 and $0.7 \mathrm{ng} \cdot \mathrm{ml}^{-1}$. After reaching a peak at the time of ligation of drainage vein from the tumour, plasma catecholmines rapidly decreased to the preoperative levels, but the blood pressure was well maintained in all cases. Ventricular arrhythmias did not occur despite the increased levels of endogenous catecholamines.

These findings suggest that morphine can be used as an alternative anaesthetic agent during operation for phaeochromocytoma and that exaggerated pressor responses to morphine (when given slowly) seem not to occur in phaeochromocytoma.

\section{Key words}

ANALGESICS: morphine; SURGERY; phaechromocytoma.

From the First Department of Surgery and the Department of Anesthesiology, Osaka University Medical School, and the Department of Biochemistry, College of Bio-medical Technology and Nursing, Osaka University.

Address correspondence to: Dr. M. Hamaji, First Dept. of Surgery, Osaka University Medical School, Fukushima-Ku, Osaka 553 Japan.
Surgical treatment of phaeochromocytoma is much less hazardous with the use of adrenergic receptor blockade, vasodilators and blood volume replacement before operation; however, the choice of anaesthetic agents still remains important. Among the anaesthetic agents currently used, neuroleptoanalgesia and enflurane are most popular. Morphine is rarely used because it is a potential releaser of histamine, ${ }^{1,2}$ which in turn leads to catecholamine release from the sympathetic nerve endings. Indeed, histamine has been used as a provocative test in the diagnosis of phaeochromocytomas, but it is unclear if the endogenous histamine liberated by morphine enhance catecholamine release and provoke a hypertensive attack. Clinical effects of morphine on blood pressure in phaeochromocytoma patients are not consistent; they include prolonged hypertension followed a dose of $10 \mathrm{mg}$ of diamorphine ${ }^{3}$ while there were no apparent adverse effects in patients given $5 \mathrm{mg}$ of morphine sulfate as premedication. ${ }^{4-7}$ Furthermore, morphine itself does not significantly depress cardiac function and has remarkable peripheral vasodilating effects which reduce peripheral vascular resistance and increase venous capacitance ${ }^{8-10}$ In patients with phaeochromocytomas, cardiac function is often impaired because of catecholamine-induced myocardial damage and longstanding pressure overload. ${ }^{11,12}$ Thus, we postulated that, if morphineinduced histamine release was not so extensive as to evoke hypertension, morphine might be an acceptable anaesthetic agent for use during excision of phaeochromocytomas.

\section{Case report}

Three patients with unilateral adrenal tumours and the two with bilateral adrenal tumours were studied. Hypertension was paroxysmal in four and sustained in one (Table I). The ECG was abnormal in four of 
TABLE I Clinical profiles of five cases of phaeochromocytoma studied

\begin{tabular}{llllll}
\hline & Case-I & Case-2 & Case-3 & Case-4 & Case-5 \\
\hline Age and Sex & $37 \mathrm{M}$ & $33 \mathrm{M}$ & $65 \mathrm{~F}$ & $51 \mathrm{~F}$ & $44 \mathrm{M}$ \\
Hypertension & paroxysmal & paroxysmal & paroxysmal & sustained & paroxysmal \\
Blood pressure & $125 / 80$ & $120 / 80$ & $140 / 80$ & $160-200 / 120$ & $150 / 76$ \\
$\quad$ (at attack) & $(210 / 130)$ & $(220 / 160)$ & $(200 / 120)$ & & $(200 / 140)$ \\
EKG findings & CRBBB & LV strain & LVH & LV strain & normal \\
Venous level of & E: 0.48 & E: 0.25 & E: 0.38 & & E: 0.4 \\
\multicolumn{1}{c}{ catecholamines } & NE: 2.1 & NE: 0.50 & NE: 0.17 & - & NE: 1.5 \\
\hline
\end{tabular}

CRBBB: complete right bundle branch block, LVH: left ventricular hypertrophy, E: plasma epinephrine (ng/ml), NE: plasma norepinephrine (ng/ml)

the five and venous levels of catecholamines were increased in three of the four patients studied; epinephrine (E) predominantly increased in one and both epinephrine and norepinephrine (NE) in two. Phenoxybenzamine $\left(0.5 \mathrm{mg} \cdot \mathrm{kg}^{-1} \cdot \mathrm{day}^{-1}\right)$ was given for one week before operation. After premedication with intramuscular hyoscine $(0.5 \mathrm{mg})$ and diazepam (20 $\mathrm{mg}$ ) or meperidine $(50 \mathrm{mg}$ ), anaesthesia was induced with a drip infusion of morphine sulfate $\left(1 \mathrm{mg} \cdot \mathrm{kg}^{-1}\right)$, over a $30 \mathrm{~min}$ period. When half the dose had been given, orotracheal intubation was carried out. Adequate depth of anaesthesia was maintained with diazepam, nitrous oxide and oxygen, and relaxation was obtained with pancuronium bromide. ECG, and arterial and central venous pressures were monitored. Phentolamine, sodium nitroprusside and propranolol were infused as required by fluctuations in blood pressure or by tachycardia.

Blood samples were obtained through an indwelling catheter placed in a peripheral vein before induction of anaesthesia and thereafter from a radial artery. Plasma catecholamine were determined using an automated fluorometric method coupled with liquid chromatography, as previously reported. ${ }^{13}$

Changes in arterial blood pressure and plasma catecholamine are summarized in Table II. During the anaesthetic induction by morphine infusion, blood pressure was stable and there were small increments of plasma catecholamines in two patients (Cases 2 and 4). The former patient was given hydroxyzine $(50 \mathrm{mg})$ with the same premedication as the other patients. In three patients, blood pressure increased concomitantly with orotracheal intubation. The increases of plasma NE were 1.1 and $1.3 \mathrm{ng} \cdot \mathrm{ml}^{-1}$ in two patients, but in Case 3 , the plasma sample was improperly taken. All these changes were transient and returned to the preoperative levels before the operation started. Adrenergic blockers were not required. Surgical manipulation of the tumour evoked marked fluctuation of blood pressure and considerable changes in plasma catecholamines in all cases. Within $30 \mathrm{~min}$ after removal of the tumour, plasma catecholamines rapidly decreased to the preoperative levels and no ventricular arrhythmias appeared, even at the peak of the blood pressure elevations. There were no patients in whom vasopressors were required to prevent circulatory collapse.

The anaesthetic course and changes in plasma catecholamines in Case 1 are briefly described.

Case 1 (Figure): This 37-year-old man had had occasional bouts of hypertension and weight loss of two years duration. Blood pressure ranged from $125 / 50$ to $210 / 130 \mathrm{mmHg}$. ECG revealed first degree A-V block and complete right bundle branch block. Peripheral venous level of catecholamines at rest was $0.48 \mathrm{ng} \cdot \mathrm{ml}^{-1}$ of $\mathrm{E}$ and $2.1 \mathrm{ng} \cdot \mathrm{ml}^{-1}$ of NE. After premedication with intramuscular hyoscine ( $0.4 \mathrm{mg}$ ) and diazepam (20 $\mathrm{mg}$ ), anaesthesia was induced as described above. Blood pressure increased $15 \mathrm{mmHg}$ and a concomitant elevation of plasma NE was noted at the time of orotracheal intubation. NE levels returned to the preinduction state before the start of operation. Immediately after initiation of surgical manipulation, plasma catecholamine levels abruptly increased and reached a peak of $6.2 \mathrm{ng} \cdot \mathrm{ml}^{-1}$ of $E$ and $17.2 \mathrm{ng} \cdot \mathrm{ml}^{-1}$ of NE. Blood pressure fluctuated widely despite phentolamine infusion. Propranolol $(1.0 \mathrm{mg})$ was given at the appearance of tachycardia. After ligation of the drainage vein from the tumour, plasma catecholamines rapidly decreased to the preoperative level 
TABLE II Alterations in systemic blood pressure and plasma catecholamines

\begin{tabular}{|c|c|c|c|c|c|c|c|c|c|}
\hline & \multicolumn{3}{|l|}{ Case-1 } & \multicolumn{3}{|l|}{ Case-2 } & \multicolumn{3}{|l|}{ Case-3 } \\
\hline & B.P. & $E$ & $N E$ & $B . P$ & $E$ & $N E$ & $B \cdot P$ & $E$ & $N E$ \\
\hline \multicolumn{10}{|l|}{ Anaesthetic Induction } \\
\hline $\begin{array}{l}\text { Before the infusion } \\
\text { After the start of }\end{array}$ & $100 / 50$ & 0.34 & 1.85 & $150 / 90$ & 0.54 & 0.42 & $160 / 90$ & 0.38 & 0.17 \\
\hline infusion & $105 / 70$ & 0.29 & 2.02 & $150 / 90$ & 0.46 & 0.81 & $140 / 80$ & 0.51 & 0.28 \\
\hline $\begin{array}{l}\text { At orotracheal } \\
\text { intubation }\end{array}$ & $120 / 110$ & 0.21 & 3.11 & $145 / 90$ & 0.26 & 0.91 & $200 / 120$ & - & - \\
\hline \multicolumn{10}{|l|}{ During the operation } \\
\hline $\begin{array}{l}\text { Peak level } \\
\text { After removal of the }\end{array}$ & $180 / 110$ & 6.20 & 17.2 & $215 / 100$ & 10.4 & 23.9 & $220 / 110$ & 17.3 & 2.50 \\
\hline \multirow{3}{*}{$\begin{array}{l}\text { After removal of the } \\
\text { tumour }\end{array}$} & $140 / 90$ & 0.97 & 1.70 & $140 / 80$ & 1.10 & 2.10 & $120 / 75$ & 0.56 & 0.33 \\
\hline & \multicolumn{3}{|l|}{ Case-4 } & \multicolumn{3}{|l|}{ Case-5 } & & & \\
\hline & B.P. & $E$ & $N E$ & $B . P$ & $E$ & $N E$ & & & \\
\hline \multicolumn{10}{|l|}{ Anaesthetic Induction } \\
\hline $\begin{array}{l}\text { Before the infusion } \\
\text { After the start of }\end{array}$ & $130 / 85$ & 0.30 & 1.0 & $130 / 90$ & 0.44 & 1.4 & & & \\
\hline infusion & $155 / 90$ & 0.50 & 0.73 & $145 / 90$ & 0.44 & 1.0 & & & \\
\hline $\begin{array}{l}\text { At orotracheal } \\
\text { intubation }\end{array}$ & $150 / 105$ & 0.32 & 1.43 & $170 / 105$ & 0.48 & 2.3 & & & \\
\hline \multicolumn{10}{|l|}{ During the operation } \\
\hline Peak level & $215 / 105$ & 14.0 & 13.0 & $210 / 100$ & 1.1 & 13.6 & & & \\
\hline $\begin{array}{l}\text { After removal of the } \\
\text { tumour }\end{array}$ & $150 / 105$ & 0.62 & 1.32 & $160 / 100$ & 0.7 & 1.3 & & & \\
\hline
\end{tabular}

B.P.: arterial blood pressure ( $\mathrm{mmH}$ ), E: plasma epinephrine, NE: plasma norepinephrine (ng/ml)

while the blood pressure remained elevated before gradually decreasing on the following day. Arrhythmias were absent, even at peak of plasma catecholamines and blood pressure. The ECG was normal postoperatively.

\section{Discussion}

The anaesthetic management of patients with phaeochromocytomas remains a challenge for anaesthetists and has been directed toward the preservation of cardiovascular stability and smooth withdrawal from the chronic excess catecholamine state. In addition to preoperative use of adrenergic receptor blockade and expansion of the contracted blood volume, the proper choice of anaesthetic technique minimizes the surgical hazards. A variety of anaesthetic agents have been successfully used. ${ }^{7,14}$ There is no previous report of morphine anaesthesia for phacochromocytomas and it had been considered that the use of morphine should be avoided.

In recent years, enflurane has became the agent of choice for phaeochromocytomas, ${ }^{15-19}$ since it is less arrythmogenic ${ }^{20}$ and is associated with less hypertension. ${ }^{19}$ Isoflurane was proposed for patients with phaeochromocytoma and associated cerebral abnormalities or impaired renal function, ${ }^{21}$ since this agent does not produce EEG abnormalities and is metabolized less than enflurane. Methoxyflurane and fluroxene are seldom used, because of the potential for nephrotoxicity (methoxyflurane) and flammability (fluroxene) although these agents are less arrhythmogenic. ${ }^{22.23}$ Halothane depresses the sympathoadrenal system but sensitizes the heart to catecholamines, resulting in a high incidence of arrhythmias. ${ }^{24}$ Neuroleptoanalgesia, with combination with droperidol and fentanyl, ${ }^{6,25}$ 


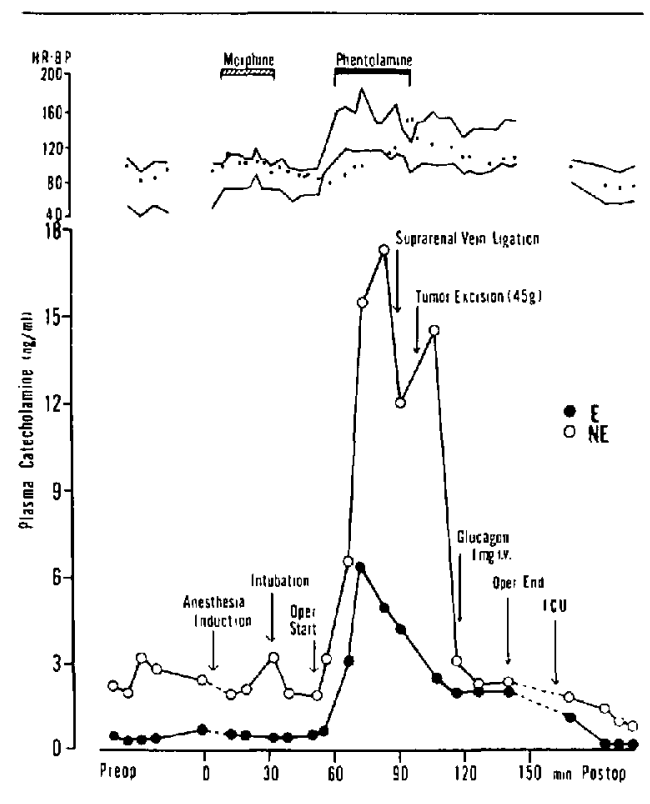

FIGURE Plasma catecholamines, blood pressure and heart rate during phacochromocytoma resection in a 37-year-old patient (case 1).

has been used. However, droperidol occasionally produce hypertension in these patients. ${ }^{26}$

Induction with thiopentone has been most frequent, but is often accompanied by hypertension and increased plasma catecholamines. Of interest is whether or not slow anaesthetic induction may cause less haemodynamic changes than those of rapid induction. We infused morphine slowly, over a period of 30 minutes. Blood pressure was unchanged in two patients, slightly increased in two. In the remaining patient whose blood pressure was moderately increased, the depth of anaesthesia appeared to be insufficient to suppress stimulation of the sympathoadrenal system. Slow induction of anaesthesia by morphine infusion did not produce an exaggerated pressor response in any patient studied and proved to be effective in maintaining cardiovascular stability during the induction.

Little information is available concerning the haemodynamic effects of morphine in patients with phaeochromocytomas. Rosow et al. reported a significant rise of plasma histamine levels following $1 \mathrm{mg} \cdot \mathrm{kg}^{-1}$ of morphine and found that the reduction of systemic vascular resistance was inversely correlated to plasma histamine in patients undergoing coronary bypass operation. ${ }^{2}$ We infused morphine three times slower than did Rosow, but histamine levels might increase in repsonse to morphine infusion. From our observations in the five patients, it appears the peripheral vasculature may have been insensitive to the vasodilating action of morphine, perhaps due to an increased sympathetic tone. We speculate that unless a large amount of histamine is released by morphine, peripheral vasodilatation might be immediately reversed by reflex stimulation of the sympathetic nervous system. The phenoxybenzamine given for one wcek before operation likely attenuated the pressor effect of morphine in our patients. The measurement of plasma histamine will be necessary to clarify the pharmacologic actions of morphine in patients with phaeochromocytomas.

Large changes in plasma catecholamines occurred during the operative manipulation of the tumour, similar to previous reports with other anaesthetic agents. ${ }^{6,16,18,27}$ Unlike the rapid recovery of catecholamines, blood pressure was maintained at high levels for several hours after removal of the tumour. We assume the sympathetic nervous system remains involved in the preservation of blood pressure after tumor removal. However, the pharmacologic effects of morphine are uncertain: some have reported stimulation, 8,28 while others found reflex reduction of sympathetic discharge following morphine-induced haemodynamic change $e^{9,10}$ or postulated specific interaction with an opioid receptor in the brain, resulting in the suppression of sympathetic outflow. ${ }^{29}$ The direct local action of morphine on the adrenergic receptors in peripheral vasculature is not clear. ${ }^{30,31}$ In addition, supplement such as nitrous oxide and diazepam produce significant obtundation of the sympathetic nervous system and cardiovascular responses, in contrast to the use of morphine alone. ${ }^{32}$

Our experience suggests that morphine warrants further consideration as an anaesthetic agent for use during phaeochromocytoma resection, but that further studies are required. 


\section{References}

1 Thompson WL, Walton RP. Elevation of plasma histamine levels in the dog following administration of muscle relaxants, opiates and macromolecular polymers. J. Pharmacol Exp Ther 1964; 143 :

$131-6$.

2 Rosow CE, Moss J. Philbin DN, Savarese IJ. Histamine release during morphine and fentanyl anesthesia. Anesthesiology 1982; 56: 93-6.

3 Chaturvedi NC, Walsh MJ, Boyle DMCC, Berber $J M$. Diamorphine induced attack of paroxysmal hypertension in pheochromocytoma. Br Med J 1974; 2: 538 .

4 El-Naggar M, Suerle E, Rosenthal E. Sodium nitroprusside and lidocaine in the management of pheochromocytoma. Can Anaesth Soc J 1977; 24: 353 60.

5 Jones RM, Hill AB. Severe hypertension associated with pancuronium in the management of pheochromocytoma. Can Anaesth Soc J 1981; 28: 394-6.

6 Takki S, Jäätela A, Tammisto T, Nikki P. Plasma catecholamine levels during the removal of pheochromocytoma. Ann Clin Res 1972; 138-45.

7 Pratilas V, Pratila MG. Anesthetic management of pheochromocytoma. Can Anaesth Soc J 1979; 26: 253-9.

8 Vasko JS, Henny RP, Brawley RK. Effects of morphine on ventricular function and myocardial contractile force. Am J Physiol 1966; 210: 329-34.

9 Lowenstein E, Whiting RB, Bittar DA. Sanders $C A$, Powell WJ Jr. Locally and neurally mediated effect of morphine on skeletal muscle vascular resistance. J Pharmacol Exp Ther 1971; 56: 93-6.

10 Zelis R, Mansour EJ, Capone RJ, Mason DT, The cardiovascular effects of morphine; the peripheral capacitance and resistance vessels in human subjects. J Clin Invest 1974; 54: 1247-58.

11 Kline $1 K$. Myocardial alterations associated with pheochromocytoma. Am J Path 1961; 38: 539-47.

12 Van Vliet $P D$, Burchell HB, Titus $J L$. Focal myocarditis associated with pheochromocytoma. N Engl J Med 1966; 274: 1102-8.

13 Hamaji $M$, Seki $T$. Estimation of catecholamines in human plasma by ion-exchange chromatography coupled with fluorometry. J Chromatogr 1979; 163 : 329-36.

14 Van Way CW, Scott HW Jr, Page DL, Rhamy RK. Pheochromocytoma. Curr Probl Surg 1974; 1: 45-7.
15 Kopriva $C K$, Eltringhan $R$. The use of enflurane during resection of a pheochromocytoma. Anesthesiology 1974; 41 : 399-400.

$16 \mathrm{Kreul} \mathrm{JF}$, Dauchot RJ, Anton AH. Hemodynamic and catecholamine studies during pheochromocytoma resection under enflurane anesthesia. Anaesthesia 1976; 44: 265-8.

17 Janeczko GF, Ivankovich AD, Glisson SN, Heyman HJ, El-Etr AA, Albrecht RF. Enflurane anesthesia for surgical removal of pheochromocytoma. Anesth Analg 1977; 56: 62-7.

18 Feldman JE, Blalock JA, Fagraues L, Miller JN, Farrell RE, Weil SA. Alterations in plasma norepinephrine concentration during surgical resection of pheochromocytoma. Ann Surg 1978; 188: 758-68.

19 van Heerden JA, Sheps SG, Hamberger B, Sheedy $P F$, Poston JG, Remine WH. Pheochromocytoma: current status and changing trends. Surgery 1982; 91: 367-73.

20 Johnston RR, Eger EL, Wilson C. Comparative interaction of epinephrine with enflurane, isoflurane and halothane in man. Anesth Analg 1976; 55 : 709-12.

21 Suzukawa M, Michaels Ira AL, Ruzbarsky J, Kopriva CJ, Kitahata LM. Use of isoflurane during resection of pheochromocytoma. Anesth Analg $1983 ; 62: 100-3$.

22 Crout JR, Brown BR. Anesthetic management of pheochromocytoma the value of phenoxybenzamine and methoxyflurane. Anesthesiology 1969; 30: 29-36.

23 Joas $T A$, Craig $D$. Fluroxene anesthesia for pheochromocytoma removal. JAMA 1969; 209: 927-9.

24 Cooperman $L H$, Engelman $K$, Mann $P$. Anesthetic management of pheochromocytoma employing halothane and beta-adrenergic blockade a report of fourteen cases. Anesthesiology 1967; 28: 575-82.

25 Clarke AD, Tobias MA, Challen PD. The use of neurolcptoanalgesia during surgery for phaeochromocytoma. Br J Anaesth 1972; 44: 1093-6.

26 Sumikawa $K$, Amakata $Y$. The pressor effect of droperidol in a patient with pheochromocytoma. Anesthesiology 1977; 46: 359-61.

27 Roizen MF, Hunt TK, Beaupre PN et al. The effect of alpha-adrenergic blockade on cardiac performance and tissue oxygen delivery during excision of pheochromocytoma. Surgery 1983; 94: 941-5.

28 Kayaap SO, Kaymacalan S. Studies on the 
morphine-induced release of catecholamines from the adrenal glands in the dogs. Arch Int Pharmacodyn 1968; 172: 139-46.

29 Toborsky GJ Jr. Halter JB, Porte D Jr. Morphine suppresses plasma response to laparotomy, but not to deoxyglucose. Am J Physiol 1982; 242: 317-22.

30 Samuel IO, Dundee JW. Circulatory effects of morphine. Br J Anaesth 1975; 47: 1025-6.

31 Ward $J M, M c G r a t h R L$, Weil JV. Effects of morphine on the peripheral vascular response to sympathetic stimulation. Am J Physiol 1972; 29: 659-66.

32 Stoelting RK, Gibbs PS. Hemodynamic effects of morphine and morphine-nitrous oxide in valvular heart disease and coronary artery disease. Anesthesiology $1973 ; 38$ : 45-52.

\section{Résumé}

Chez cinq malades, on a effectué une résection d'un phéochromocytome sous anesthésie à la morphine en mesurant, durant l'intervention, les fluctuations des concentrations des catécholamines plasmatiques. Les malades ont êté préparés à la phénoxybenzamine 10.5 $m g \cdot \mathrm{kg}^{-1} \cdot$ jour $\left.{ }^{-1}\right)$ administrée par voie orale dans la semaine précédant l'intervention. A la suite d'une prémédication faite d'hyoscine $(0.4 \mathrm{mg})$ et de diazépam $(20 \mathrm{mg})$ ou de mépéridine $(50 \mathrm{mg})$, on a induit l'anesthésie par une infusion de sulfate de morphine ( $1 \mathrm{mg} \cdot \mathrm{kg}^{-1}$ ) sur une période de 30 minutes, complétée de diazépam. de protoxyde d'azote, d'oxygène et de bromure de pan. curonium. Chez trois de ces cinq malades on a observé une augmentation transitoire de la pression artérielle de 15 à $60 \mathrm{mmHg}$ au moment de l' intubation orotrachéale, mais cette augmentation n'a pas nécessité de vasodilatateurs. Chez deux de ces trois malades, on a observé une augmentation de la norépinéphrine plasmatique de 1.1 et $1.3 \mathrm{ng} \cdot \mathrm{ml}^{-1}$ respectivement. Chez les deux autres malades dont la pression artérielle est restée stable, les concentrations de norépinéphine plasmatique étaient respectivement de 0.1 et $0.7 \mathrm{ng} \cdot \mathrm{ml}^{-1}$. Une fois atteint le pic de concentration des catécholamines plasmatiques au moment de la ligature de la veine drainant la tumeur, les concentrations ont rapidement diminué au niveau préopératoire alors que la pression artérielle demeurait stable en tout temps. Aucune arythmie ventriculaire n'est apparue en dépit de ces variations des catécholamines endogènes. Ces constatations suggèrent que la morphine constitue un agent anesthésique acceptable pour la résection d'un phéochromocylome car les flambées hypertensives en réponse à la morphine administrée lentement ne semblent pas survenir en présence d'un phéochromocytome. 